\title{
Subantarctic copepods in an oceanic, low chlorophyll environment: ciliate predation, food selectivity and impact on prey populations
}

\author{
A. Atkinson* \\ British Antarctic Survey, Natural Environment Research Council, High Cross, Madingley Road, Cambridge CB3 0ET, \\ United Kingdom
}

\begin{abstract}
Copepod feeding rates and food selectivity were measured at an oceanic subantarctic site over 5 d in February 1994. A series of gut fluorescence and gut evacuation experiments was carried out for species ranging in size from Oithona similis to Pleuromamma robusta. The copepods were also incubated in ambient seawater to compare their clearance rates on ciliates, diatoms and total chlorophyll a (chl a), using microscope counts and chlorophyll budgets. Mesozooplankton were concentrated into the top $50 \mathrm{~m}$ layer where biomass was high $\left(5.5 \mathrm{~g}\right.$ dry mass $\left.\mathrm{m}^{-2}\right)$ and comprised mainly $\left(65^{\prime}\right.$ ', of copepods. Copepod biomass was dominated by copepodite $\mathrm{CV}$ of Calanus simillimus. Numerically, however, Oithona spp. (mainly $O$. similis) constituted $85 \%$ of the copepods. These 2 species dominated copepod grazing and contributed to community grazing in about equal proportions. Chl a concentrations were low ( $\left.0.7 \mathrm{mg} \mathrm{m}^{-3}\right)$ and were comprised of mostly nano- and picoplankton. Low daily phytoplankton carbon rations were denved from the 2 methods which measured total chl a consumption. These ranged from $1.5 \%$ (CVlo C. simillimus) to $34 \%$ of body carbon (late stage copepodites of Oithona spp.). These values were generally well below their estimated respiratory requirements, and probably reflected phytoplankton shortage because clearance rates were fairly high. Clearance rates for total chl $a$ in the incubations tended to be less than those for the counted taxa $>10 \mu \mathrm{m}$, suggesting that some of the chl a was in cells too small to be eaten. Feeding selectivity followed a similar pattern across the 4 incubations. Highest clearance rates were on ciliates $(\sim 15 \mu \mathrm{m})$, dinoflagellates $(\sim 20 \mu \mathrm{m})$ or the diatom Corethron sp. $(\sim 200 \mu \mathrm{m})$. Ciliates and dinoflagellates were cleared faster than centric diatoms of similar overall dimensions. It is suggested that the copepods were preying on protozoans preferentially, in response to phytoplankton shortage. Allometric relationships were used to derive the grazing and predation impact of the whole copepod community on primary production and estimated ciliate production. Less than $4 \%$ of primary production was removed per day. Copepod predation on ciliates was higher: $57 \%$ of daily production, assuming a net growth rate for ciliates of $0.1 \mathrm{~d}^{-1}$
\end{abstract}

KEY WORDS: Subantarctic $\cdot$ Copepods $\cdot$ Selective feeding $\cdot$ Ciliates · Allometry

\section{INTRODUCTION}

Oceanic environments often have low chlorophyll levels for much of the year. In the northeast Pacific, much of the chlorophyll is in cells near the lower size limit for ingestion by copepods (Frost et al. 1983, Berggreen et al. 1988, Gifford 1993a), so herbivores could face a shortage of suitable phytoplankton food for most of the year. Conversely, the impact of oceanic copepods on phytoplankton stocks tends to be low

\footnotetext{
•E-mail: aat@pcmallnerc-bas.ac.uk
}

(Tsuda et al. 1989, Morales et al. 1991, 1993, Dagg 1993). Protozoans appear to be the major grazers of primary production in the northeast Pacific (Landry et al. 1993) and possibly in parts of the Southern Ocean (see Garrison 1991، Burkill et al. in press). Protozoans in turn may form an essential part of the diets of marine copepods (e.g. Gifford \& Dagg 1991, Gifford 1993a), allowing them to survive and reproduce between phytoplankton blooms (White \& Roman 1992, Ohman \& Runge 1994). This line of reasoning suggests that copepods might survive phytoplankton shortages partly by preying on protozoans, thus regulating proto- 
zoan populations (Gifford 1993a, Fessenden \& Cowles 1994).

This suggestion was addressed at a midocean site in the Antarctic Polar Frontal Zone. The study area is a large, circumpolar mixing zone of Antarctic and subantarctic water which has rarely been studied, in comparison to subpolar oceans to the north. In common with the northeast Pacific, it is a high nutrient, low chlorophyll zone that supports large mesozooplankton stocks (Foxton 1956, Hopkins 1971). The site was visited in midsummer, when chlorophyll levels were only $\sim 0.7 \mathrm{mg} \mathrm{m}^{-3}$ and were comprised of cells mainly $<20 \mu \mathrm{m}$. Large numbers of copepods were feeding in the surface mixed layer. Three approaches were used to elucidate which food sources were being utilized and to provide independent estimates of feeding rates. These were the gut fluorescence method, incubations in natural seawater to monitor chlorophyll uptake by copepods, and microscope counts of food items in the incubation water to compare removal rates of protozoan and phytoplankton taxa. Of central interest were 3 questions: (1) Was phytoplankton intake sufficient to have fulfilled the metabolic needs of the copepods? (2) Were copepods clearing ciliates faster than diatoms of equivalent size (i.e. were they actively selecting ciliates)? (3) Were copepods removing significant proportions of ciliate and phytoplankton stocks?

Assessments of community grazing should account for small copepods, which can dominate numerically and may have much higher mass specific feeding rates than the larger species which are more amenable to study (Paffenhöfer 1971, 1988, Stoecker \& Egloff 1987, Morales et al. 1991). Thus, an allometric approach was used in an attempt to estimate a realistic feeding rate of the whole copepod community. This was done by constructing body mass-feeding rate regressions which were based on copepods ranging over 300 -fold in body mass.

\section{METHODS}

In midsummer 1994, the RRS 'James Clark Ross' occupied a station at $49^{\circ} 47^{\prime} \mathrm{S}, 37^{\circ} 27^{\prime} \mathrm{W}$, a subantarctic site north of South Georgia in the Atlantic sector of the Southern Ocean. This study covered feeding rates and selectivity of copepods in the top $50 \mathrm{~m}$ at the site, which was sampled over a 5 d period (8 to 12 February).

Copepod abundance estimates. Two zooplankton samplers were used: a $0.75 \mathrm{~m}$ diameter, $200 \mu \mathrm{m}$ mesh ring net, hauled vertically at $-0.15 \mathrm{~m} \mathrm{~s}^{-1}$, and a Longhurst Hardy Plankton Recorder (LHPR) with a $20 \mathrm{~cm}$ aperture nose cone. Zooplankton abundance was estimated from 13 hauls $(0$ to $50 \mathrm{~m}$ ) with the ringnet and from 5 double oblique $(0$ to $200 \mathrm{~m})$ stratified
LHPR hauls (A. Atkinson, P. Ward, E. J. Murphy \& R. S. Shreeve unpubl.). The ringnet abundance estimates were taken as an average of the 13 hauls, assuming $100 \%$ filtration efficiency. Flowmeters were mounted on the LHPR, and because this sampler yielded higher abundance estimates overall (no. $\mathrm{m}^{-3}$ ) than the ringnet (Atkinson et al. unpubl.), the LHPR data were used here. The LHPR was fished with a 1 min sampling interval and $30 \mathrm{~min}$ fishing time and the PROPLUS control system enabled hauling speed and ship speed to be adjusted so that each sample represented about 5 to $8 \mathrm{~m}^{3}$ of water filtered. The samples were fomaldehyde preserved and analysed using standard techniques (see Atkinson et al. 1992).

Two methods were used to estimate the abundance of early copepodites of Oithona spp. and pseudocalaniids, which were too small for retention by the $200 \mu \mathrm{m}$ net. First, hauls were made consecutively with a $100 \mu \mathrm{m}$ and a $200 \mu \mathrm{m}$ ring net on 2 occasions, and the abundance of individuals missed by the coarser mesh was calculated as the difference between the estimates of the 2 nets. The second method was to determine their abundance in the initial and final control water samples of the incubation experiments (see 'Feeding experiments' below). This method provided lower estimates of Oithona abundance than the nets (3259 versus 4520 ind $\mathrm{m}^{-3}$ ), so the mean of these was used to estimate community grazing

Feeding rates measured by the gut fluorescence method. Five nighttime and 5 daytime gut evacuation experiments were carried out, in order to construct a diel picture of gut fullness and evacuation rate. The nighttime hauls were mainly made on the night of 11-12 February, whereas the daytime hauls were made in the early mornings and afternoon/evenings of the $5 \mathrm{~d}$ occupation of the site. Immediately on retrieval of the net, the contents of the 51 solid codend were transferred to a $200 \mu \mathrm{m}$ sieve immersed in $0.2 \mu \mathrm{m}$ filtered seawater. About one-quarter of the sieve contents was frozen at $-60^{\circ} \mathrm{C}$, while the remainder was rapidly rinsed in another bucket of filtered seawater and transferred to $20 \mathrm{l}$ of filtered seawater at ambient temperature $\left(6\right.$ to $7^{\circ} \mathrm{C}$ ). This carboy was placed in a darkened incubator and at intervals of 10,20,30 and $45 \mathrm{~min}$, the copepods were mixed by gentle inversion, a 5 l subsample was removed and the zooplankton were frozen. Three more 0 to $50 \mathrm{~m}$ hauls were not used for gut evacuation experiments, but their entire contents were immediately frozen as in the initial samples from the gut evacuation experiments.

The frozen samples were analysed in the United Kingdom within 7 mo of collection. To minimise any pigment degradation, portions of each subsample were sucessively thawed in filtered seawater and sorted as quickly as possible. A dim light source was used for the 
microscope sorting and temperature maintained at $\sim 0^{\circ} \mathrm{C}$ by ice chips in a petri dish. Nine of the dominant species and stages were sorted into centrifuge tubes containing $6.5 \mathrm{ml}$ of $90 \%$ aqueous acetone. Two replicate batches of 35 to 40 individuals of Calanus simillimus CIV, C simillimus CV and one batch of $90 \mathrm{Oi}$ thona spp. were processed per timepoint. Oithona spp. were picked without regard for species and stage, and constituted $>90 \%$ late stage copepodites and adults of $O$. similis, the remainder being its larger congener $O$. frigida. The remaining species/stages were rarer: $\mathrm{C}$. simillimus CIII, CVIo, Neocalanus tonsus CV, Pleuromamma robusta CVIo, Metridia lucens CVo and Clausocalanus laticeps CVIo. These were processed in average single batches of $47,12,20,10,15$ and 14 individuals per timepoint respectively.

Simple tests showed that complete extraction was achieved overnight in the dark at $0^{\circ} \mathrm{C}$, without the need for homogenisation. The tube contents were then mixed and centrifuged at $3500 \mathrm{rpm}$ for $30 \mathrm{~min}$. The fluorescence of the supernatant was then measured on a Turner 112 fluorometer before and after acidification. Chlorophyll (chl a) and phaeopigment content of the copepods were calculated using the equations in Parsons et al. (1984).

Gut pigment contents were calculated as the sum of the chl $a$ and phaeopigments, although the former usually comprised $<10 \%$ of the latter. The extent of pigment degradation to nonfluorescent compounds was not assessed, so the pigment values were multiplied by 1.5 to give an allowance for the range of losses most frequently encountered (Kiørboe \& Tiselius 1987, Dam \& Peterson 1988), Several other studies (e.g. Lopez et al. 1988, Penry \& Frost 1991, Head 1992) have reported extremely variable and occasionally higher pigment losses, although even these suggest that on average only about half of the pigment is lost. The decline in gut contents over the first 30 min approximated well to a negative exponen- tial model (Atkinson et al. unpubl.), so the evacuation rate constant, $k$ (min $\left.{ }^{-1}\right)$ was calculated as

$$
P=P_{0} \mathrm{e}^{-k t}
$$

where $P$ is the gut pigment after time $t, P_{0}$ is the initial gut pigment.

The mean daytime and nighttime gut content was calculated for each of the study species; from these values and the relative lengths of day and night, diel mean pigment values $\left(m_{p}\right)$ were calculated. To standardise the wide range of grazer mass, their mean gut carbon content $(C)$ was calculated as a percentage of body carbon:

$$
C=\frac{100 m_{\mathrm{p}}(C: \operatorname{chl} a)}{0.45 m_{\mathrm{g}}}
$$

The assumptions here are that the carbon/chlorophyll ratio ( $C: \mathrm{chl}$ a) was 50 and the carbon mass of the grazers was $45 \%$ of dry mass $\left(m_{\mathrm{g}}\right)$. Daily carbon ration $(R$, percentage of body carbon ingested per day) was then calculated from:

$$
R=C \cdot k \cdot 1440
$$

where 1440 is the number of minutes in a day and $k$ is diel mean gut evacuation rate constant $\left(\mathrm{min}^{-1}\right)$. A diel mean value of $k$ was used because there were no statistically significant day/night differences in evacuation rate for any of the species (Atkinson et al. unpubl.)

Feeding experiments. Copepods for feeding experiments were obtained from slow, nonquantitative tows with the $200 \mu \mathrm{m}$ ring net from $50 \mathrm{~m}$ to the surface. Undamaged individuals were sorted from the diluted codend contents and placed in 1.21 bottles of unscreened surface seawater The predominant species and stages in the catches were selected for the 3 experiments conducted at the station (labelled $\mathrm{A}, \mathrm{B}$ and $\mathrm{C}$ in Table 1). A fourth, D, was nearer the Polar Front $8 \mathrm{~d}$

\begin{tabular}{|c|c|c|c|c|c|c|c|}
\hline \multirow[t]{2}{*}{ Species, stage } & \multirow{2}{*}{$\begin{array}{c}\text { Mean dry mass } \\
\left(\mu \mathrm{g} \text { ind. }{ }^{-1}\right)\end{array}$} & \multirow{2}{*}{$\begin{array}{l}\text { Mean } \\
\text { no. } l^{-1}\end{array}$} & \multirow{2}{*}{$\begin{array}{l}\text { Bottle volume } \\
\text { (l) }\end{array}$} & \multicolumn{4}{|c|}{ No. of bottles incubated } \\
\hline & & & & A & $\mathrm{B}$ & $\mathrm{C}$ & $\mathrm{D}$ \\
\hline Oithona spp. (CIV-CVI) & 1.54 & 80 & 0.6 or 1.2 & 1. & & 1 & 1 \\
\hline Calanus simillimus (CIII) & 17 & 25 & 0.6 or 1.2 & & 1 & 1 & 1 \\
\hline Metridiids/pseudocalaniids (CII-CV) & 24 & 28 & 0.6 or 1.2 & 1 & 1 & 1 & 1 \\
\hline Calanus simillimus (CIV) & 45 & 12 & 1.2 or 2.4 & 2 & 2 & 2 & 1 \\
\hline Metridia Iucens (CIV-CVI) & 93 & 8 & 1.2 & & 1 & & \\
\hline Calanoides acutus (CIV) & 99 & 8 & 1.2 & & & & 1 \\
\hline Calanus simillimus (CV) & 179 & 7 & 2.4 & 2 & 4 & 4 & 2 \\
\hline Neocalanus tonsus (CV) & 200 & 5 & 2.4 & 2 & 2 & 2 & \\
\hline Calanus simillimus (CVIQ) & 284 & 5 & 2.4 & 1 & & 1 & 1 \\
\hline Calanoides acutus (CV) & 351 & 7 & 2.4 & & & & 1 \\
\hline Calanus propinquus (CV) & 543 & 2 & 2.4 & & & & 2 \\
\hline
\end{tabular}
later, and is included here because the same species

Table 1. Copepods incubated in the 4 experiments ( $A$ to D), listed in ascending order of dry mass 
were incubated and the microplankton assemblage was similar. Difficulties in shipboard identification precluded the rapid separation of copepodites of Oithona spp., so they were sorted without regard for species or stage. About $50 \%$ of these were later verified as $O$. similis adults, the remainder being almost entirely their late-stage copepodites.

Natural seawater was used as a prey assemblage. This was collected from the surface with a clean plastic bucket 2 to $4 \mathrm{~h}$ before the start of each experiment, and stored at 6 to $7^{\circ} \mathrm{C}$ in the dark. Experiments were set up after the copepods had acclimated to the $1.2 \mathrm{I}$ bottles for $-18 \mathrm{~h}$. The prey assemblage was then mixed in a 50 ] carboy and siphoned through silicon tubing into glass experimental bottles. A $500 \mu \mathrm{m}$ net at the siphon intake excluded large copepods from the incubation water

Capacity of the experimental bottles $(2.4,1.2$ or 0.6 l) and the numbers of copepods $1^{-1}$ were matched against grazer size and prior experience of their feeding capabilities (Table 1). During the experiment, the aim was for the copepods to reduce the prey assemblage by about $40 \%$ at most (Gifford 1993b). Reductions of the various food taxa tended to be less than this percentage (Table 2)

After adding the copepods, a $100 \mathrm{ml}$ initial subsample was decanted and preserved in $1 \%$ acid Lugol's solution. Where replicate pairs were incubated (Table 1), one of the pair was carefully topped up with incubation water and sealed to preclude any air bubbles. Bottles were placed in darkened incubators at ambient temperature $\left( \pm 1^{\circ} \mathrm{C}\right)$ and rotated end over end for 21 to $25 \mathrm{~h}$. Two controls with no added copepods were treated in the same way. These also comprised one bottle with a $100 \mathrm{ml}$ airspace and one without.

Comparisons between bottles with and without an airspace were motivated by recent work (Saiz et al. 1992) which has shown that copepod feeding rates and behaviour can depend on the degree of turbulence. The bottles with an airspace were subjected to more violent mixing than those without. This occurred as the bottle sides approached the horizontal and the rolling of the ship rapidly transferred the bubble from one side of the jar to the other. In 37 paired comparisons of clearance rate, however, no significant differences were found between the 2 mixing methods, so the results will not be discussed further Gifford (1993b) had recommended that no airspace be used in order to reduce mortality of delicate aloricate ciliates. Although the recovery of ciliates in final controls with and without an airspace was similar to that in these experiments, I cannot exclude the possibility that losses occurred while collecting water (from the sea surface). while setting up the experiments or during preservation in the $1 \%$ Lugol's solution (Stoecker et al. 1994).

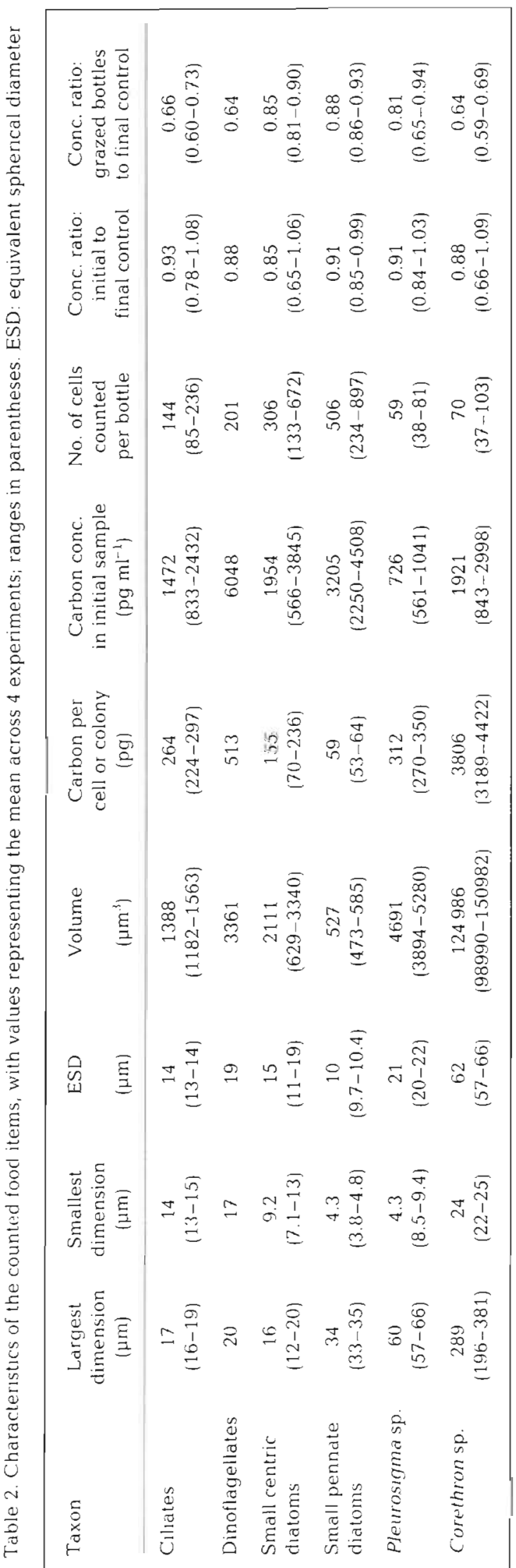


Mortality for Oithona spp. was $<6 \%$, and for the other species, negligible. At the end of the experiments, either one or two $200 \mathrm{ml}$ subsamples from each jar were preserved in $1 \%$ Lugol's solution and the copepods were frozen for dry mass measurement as described in Atkinson (in press). Estimates of community grazing required dry mass values for each of the other species and copepodite stages. Therefore, 15 to 60 individuals of each were measured, enabling the construction of length-mass regressions for calculation of their dry masses. Dry masses of other major zooplankters (euphausiids, amphipods, chaetognaths and pteropods) were obtained on formaldehyde preserved material, and the values were multiplied by 1.25 as an adjustment for tissue loss (Hopkins 1971).

Total chl a consumption was monitored in Expts A and $C$. This was done by taking a $250 \mathrm{ml}$ subsample from the initial water and from each of the bottles at the end of the experiment. These were filtered onto $\mathrm{GF} / \mathrm{F}$, extracted for $24 \mathrm{~h}$ in $6.5 \mathrm{ml}$ of acetone and analysed for chl a as described previously.

Cell counts and feeding rate calculations. Enumeration of organisms in the food assemblage was usually on 2 aliquots of $50 \mathrm{ml}$ per experimental bottle. These were settled for $24 \mathrm{~h}$ and transferred to an inverted microscope counting chamber. The microplankton assemblage, dominated by small flagellates, proved extremely difficult to evaluate fully, so no attempt was made to calculate feeding rates on the smaller cells. Instead, selected larger taxa (>10 or $15 \mu \mathrm{m})$ which were readily identifiable were targeted for counting at $200 \times$ magnification (Table 2). Counting procedure depended on abundance, being either from the whole slide, from alternate transects or from perpendicular transects across its centre. Dinoflagellates were enumerated only in experiment A, where only the individuals $>15 \mu \mathrm{m}$ were counted. Almost all of the ciliates and dinoflagellates observed were aloricate forms $<40 \mu \mathrm{m}$. Where fewer than 30 cells were counted per aliquat, clearance rates were not calculated. This precluded Corethron sp. in Expts A and $\mathrm{C}$ and Pleurosigma sp. in Expt D.

Ratios of counted cells in initial to final controls (Table 2) tended to be slightly less than unity, suggesting a tendency for cell numbers in the controls to decrease during the experiments. The differences were not consistent, however, and probably partly attributable to counting imprecision (Gifford 1993b). For consistency between taxa and experiments, clearance rates of individual taxa were calculated from Frost's (1972) equations, modified slightly to:

$$
F=\ln \left(C_{\mathrm{c}} / C_{\mathrm{g}}\right) \cdot V /\left(m_{\mathrm{g}} t\right)
$$

where $F$ is the clearance rate $\left(\mathrm{ml}\right.$ mg dry mass $\left.{ }^{-1} \mathrm{~d}^{-1}\right) ; C_{c}$ is the final concentration in control; $C_{g}$ is the final con- centration in grazer bottle; $V$ is the experimental volume $(\mathrm{ml}) ; m_{y}$ is the total dry mass of grazers in bottle (mg); and $t$ is the duration of the experiment (d).

For the 3 smallest copepod taxa (Table 1), clearance of Corethron sp. had to be calculated by replacing the $C_{r}$ term in Eq. (4) with the initial numbers of Corethron $\mathrm{sp}$. which were counted in the grazed bottles. This adjustment was needed because these long cells were transferred from the codend contents with the copepods by the $100 \mu \mathrm{m}$ sieves used for handling the smaller copepods. This elevated the initial concentrations of Corethron sp. in small copepod incubations relative to the initial controls. Clearance of total chl a was calculated using Eq. (4). Chl a ingestion rates during the incubations were calculated as the product of clearance rate of total chl a and its initial concentration in the incubation water (Marin et al. 1986). The initial chl a values were 0.71 and $0.74 \mathrm{\mu g} \mathrm{l}^{-1}$ in Expts $A$ and $C$ and the final controls were within $7 \%$ of initial values.

The lengths and widths of the food items were calculated from measurements of 20 to 40 cells, and their volumes calculated from approximations to simple geometric shapes. Carbon content of the diatoms and dinoflagellates was calculated from the equations of Eppley et al. (1970). Ciliate carbon was estimated using Putt \& Stoecker's (1989) factor of $0.19 \mathrm{pg} \mu^{-3}$ which allows for shrinkage in $2 \%$ Lugol's. The most drastic shrinkage is in stronger concentrations of Lugol's $(>10 \%)$, which preserve a higher percentage of the athecate protozoan population (Stoecker et al. 1994). Even if volume shrinkage was $50 \%$, the highest value in a range of measurements (Leakey et al. 1994a, Stoecker et al. 1994), this would likely correspond to only a $20 \%$ reduction in linear dimensions. The protozoan dimensions in Table 2 are therefore probably realistic.

\section{RESULTS}

\section{Environment}

The study site was north of the Polar Front in the Polar Frontal Zone, with mixed layer temperatures of about $6.5^{\circ} \mathrm{C}$. The thermocline was coincident with the pycnocline, which was situated at 45 to $65 \mathrm{~m}$. The feeding results from the top $50 \mathrm{~m}$ therefore pertained to the mixed layer.

Chl a levels were low overall, reaching $0.82 \mathrm{mg} \mathrm{m}^{-3}$ (J. Priddle unpubl.). One of the 3 available profiles shows a slight subsurface maximum at 20 to $30 \mathrm{~m}$, but below this depth, chl a decreased to $\sim 0.2 \mathrm{mg} \mathrm{m}^{-3}$ at $100 \mathrm{~m}$. Three-size fractionated chl $a$ and oxygen uptake measurements show a phytoplankton community almost entirely dominated by nano- and picoplankton (S. P. Blight \& J. Priddle unpubl. data). Mean percent- 
ages of chl $a$ in the $<2,2$ to 20 and 20 to $200 \mu \mathrm{m}$ fractions were 35,53 , and $12 \%$ respectively. Microplankton respiratory activity was even more slanted towards the smaller size fractions, with organisms $<2 \mu \mathrm{m}$ responsible for more than half.

\section{Community composition and abundance}

Total mesozooplankton dry mass was $110 \mathrm{mg} \mathrm{m}^{-3}$ $\left(5.5 \mathrm{~g} \mathrm{~m}^{-2}\right)$ within the top $50 \mathrm{~m}$. This constituted $65 \%$ copepods, $18 \%$ euphausiids and $14 \%$ chaetognaths plus amphipods. Information on their vertical distribution was provided by the LHPR (Atkinson et al. unpubl.). As a diel average, $81 \%$ of zooplankton biomass and $83 \%$ of numbers were in the topmost $50 \mathrm{~m}$, with extensive diel migration (i.e. across the thermoclinej only apparent for the metridiid copepods Metridia lucens and Pleuromamma robusta. This study is restricted to copepods because of their domination of biomass and numbers in the surface mixed layer.

The copepod fauna was represented by typical subantarctic species such as Calanus simillimus, Neocalanus tonsus, Clausocalanus laticeps, Clausocalanus brevipes and Metridia lucens. Copepodites CIV and CV of C. simillimus constituted $76 \%$ of copepod biomass in the top $50 \mathrm{~m}$. In contrast, these 2 stages constituted only $6.0 \%$ of mean abundance within this layer, which was dominated ( $85 \%$ ) by Oithona spp.

\section{Daily algal carbon rations based on chlorophyll consumption}

Total phytoplankton intake was measured by both the gut fluorescence and during the 2 incubations in which chl a was measured (Table 3). To enable a direct comparison of these independent methods, the same carbon:chl a and copepod carbon:dry mass assumptions were used to derive algal carbon rations. Both methods concur that the rations of the larger copepods were $<3 \%$. The gut fluorescence results suggest overall (but not consistently) higher rations than the incubations, but note that these values were multiplied by 1.5 as an allowance for an unmeasured degree of pigment destruction. Daily rations of the small copepods based on gut fluorescence were significantly higher than those of the larger individuals; this reflects both their higher diel average gut content and generally faster food throughput rates (Table 3 ). The incubation results also suggest higher daily algal carbon rations among the smaller copepods. The values in Table 3 marked by ' $a$ ' must be considered as minimum estimates because, as described in 'Methods', long cells of Corethron sp. were introduced with the smaller copepods into the grazing jars with the finer mesh sieves used for handling these copepods. This would have increased the initial chl a in the grazed jars by an unmeasured amount.

\section{Feeding selectivity}

The selective feeding patterns of the species followed similar patterns across the 4 experiments. Therefore, to ease presentation, the available results are plotted together for each grazer (Fig. 1). The largest cell measured, Corethron sp. (>50 $\mu \mathrm{m}$ equivalent spherical diameter), tended to be cleared at the highest rates. In most grazer-food interactions, ciliates and dinoflagellates were cleared faster than diatoms of similar size. Size measured as equivalent spherical diameter, how-

Table 3. Gut passage times, gut contents and daly carbon rations obtained from the gut fluorescence method and from the 2 incubations where the decrease in chl a was measured. See 'Results, Daily rations calculated from gut fluorescence' for the calculations of variables $k, C$ and $R$. Copepods are listed in order of increasing dry mass. 'Minimum estimate; see 'Results'; nd: no data

\begin{tabular}{|c|c|c|c|c|c|}
\hline \multirow[t]{3}{*}{ Species, stage } & \multicolumn{3}{|c|}{ Gut fluorescence } & \multirow{2}{*}{\multicolumn{2}{|c|}{$\begin{array}{l}\text { Daily rations from } \\
\text { incubation method }\end{array}$}} \\
\hline & \multirow{2}{*}{$\begin{array}{c}\text { Gut passage } \\
\text { ime } \min (1 / \mathrm{k} \min )\end{array}$} & \multirow{2}{*}{$\begin{array}{l}\text { Gut carbon } \\
\text { content } \%(C)\end{array}$} & \multirow{2}{*}{$\begin{array}{l}\text { Daily carbon } \\
\text { ration } \%(R)\end{array}$} & & \\
\hline & & & & Expt A & Expt $C$ \\
\hline Oithona spp. (CIV-CVI) & 41 & 0.97 & 34 & $9.5^{\circ}$ & nd \\
\hline Calanus simillmus (CII) & 41 & 0.23 & 8.1 & nd & $1.8^{d}$ \\
\hline Metridiids/pseudocalaniids (CII-CV) & nd & nd & nd & $3.0^{\mathrm{a}}$ & $2.9^{a}$ \\
\hline Clausocalanus laticeps (CVIọ) & 67 & 0.33 & 7.1 & nd & nd \\
\hline Calanus simillimus (CIV) & 61 & 0.13 & 3.2 & 5.2 & 3.5 \\
\hline Metridia lucens (CVIọ) & 120 & 0.16 & 1.9 & nd & nd \\
\hline Calanus simullumus (CV) & 48 & 0.069 & 2.1 & 1.2 & 0.85 \\
\hline Neocalanus tonsus (CV) & 47 & 0.067 & 2.1 & 3.4 & 1.6 \\
\hline Calanus simillimus (CVIo) & 100 & 0.10 & 1.5 & 0.26 & 0.63 \\
\hline Pleuromamma robusta (CVIo) & 238 & 0.34 & 2.1 & nd & nd \\
\hline
\end{tabular}




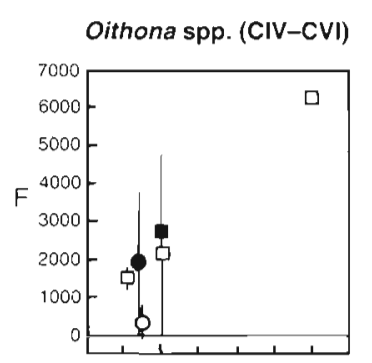

Calanus simillimus (CIII)
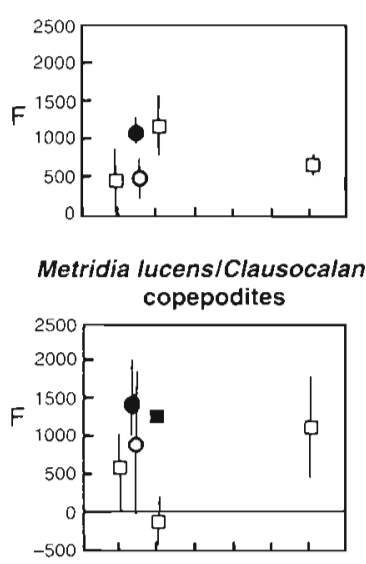

Calanus simillimus (CIV)

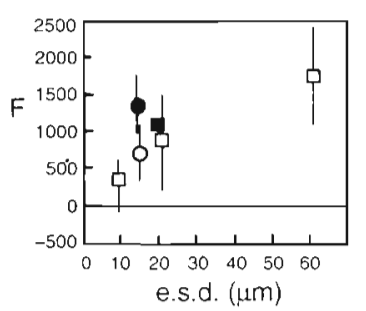

$$
\begin{array}{lll}
\text { - ciliates } & 0 \text { centric diatoms } \\
\text { - dinoflagellates } & \square \text { pennate diatoms }
\end{array}
$$
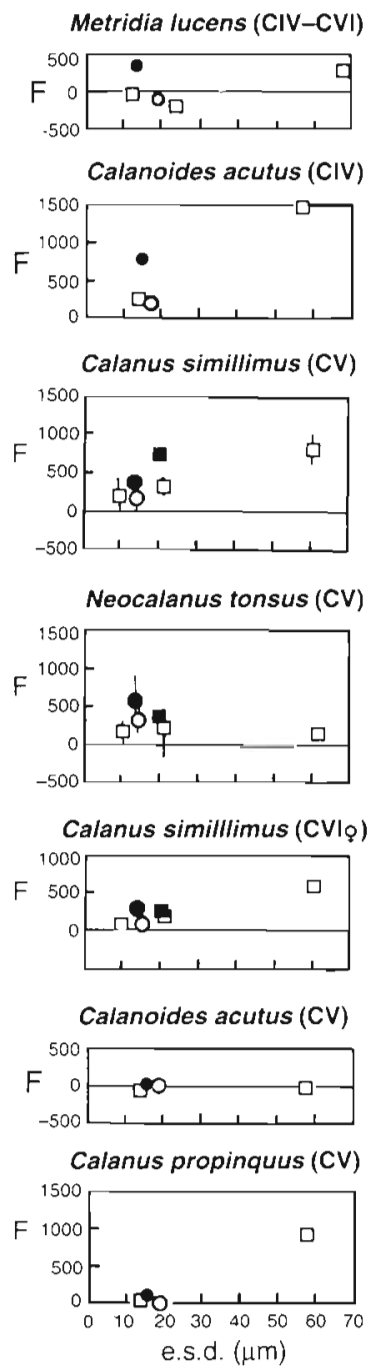

Fig. 1. Mean clearance rates of individual cell taxa by the copepods incubated in Expts A, B, C and D. Clearance rates $F$ $\left(\mathrm{ml} \mathrm{mg}^{-1} \mathrm{dry}\right.$ mass $\mathrm{d}^{-1}$ ) are plotted against mean equivalent spherical diameter (e.s.d.) of the cells (see Table 2). Note change of clearance scale between Oithona spp. and all the other species. Where a species was incubated in more than one experiment the error bars indicate ranges of clearance values between experiments

ever, disguises some appreciable differences in cell shape (Table 2): the counted ciliates, dinoflagellates and centric diatoms had similar lengths and widths, whereas pennate diatoms were long and thin. A more rigorous comparison of diatom versus protozoan clearance is therefore between ciliates and centric diatoms which are comparable in both size and shape. Table 2 also shows that they contributed similar proportions of available carbon, although ciliate biovolume in the water was only about one-third of that of centric diatoms. Of the 42 incubations performed, 36 yielded clearance rates of ciliates which were higher than those of the centric diatoms. Applying a binomial expansion to this sign distribution shows a $<0.1 \%$ chance of this happening if clearance rates on the 2 food items had been the same.

\section{Community grazing impact}

Several studies (e.g. Peters \& Downing 1984, Knoechal \& Holtby 1986) have found that body size is a major factor determining zooplankton grazing rates. Because the copepod community was comprised of many species and stages, allometric relationships between logged body mass and logged clearance rate were constructed to estimate the feeding rates of stages which were not measured directly. The purpose of using these empirical relationships was to provide a realistic evaluation of grazing by the whole copepod community. For consistency between the grazing rate methods, clearance rates rather than ingestion rates were used. The ingestion rates derived by gut fluorescence were converted to clearance rates by dividing by the maximum chl a concentration in the mixed layer (mean of 3 profiles was $0.75 \mathrm{mg}$ $\mathrm{m}^{-3}$ ). Fig. 1 shows several instances of zero or 'negative' clearance values, the latter being within the range of counting imprecision (i.e. where more cells were counted in the grazed bottle than in the ungrazed control). These were not used for regression analysis. For the individual experiments, the slopes of regressions of logged clearance on logged body mass were mainly in the range of 0.4 to 0.6 . Analysis of covariance showed that the regression slopes of the 4 experiments did not differ significantly ( $p>0.05$ ), so the data were pooled for each of the 4 food sources/ measurement methods, in order to best reflect the community at this site. These pooled data sets and regressions (Fig. 2 and Table 4) were used as the basis for estimating copepod community clearance rates.

For the copepodites measured directly, their population clearance rates were simply calculated as the product of their mean clearance rate per individual and mean abundance in the top $50 \mathrm{~m}$. This calculation was then applied to the remaining copepodites, whose clearance rates were estimated from body mass using the equations given in Table 4 . The total copepod community clearance was then obtained by summation. (Nauplii were abundant in the catches of the $100 \mu \mathrm{m}$ net but their grazing was not estimated here.) These 

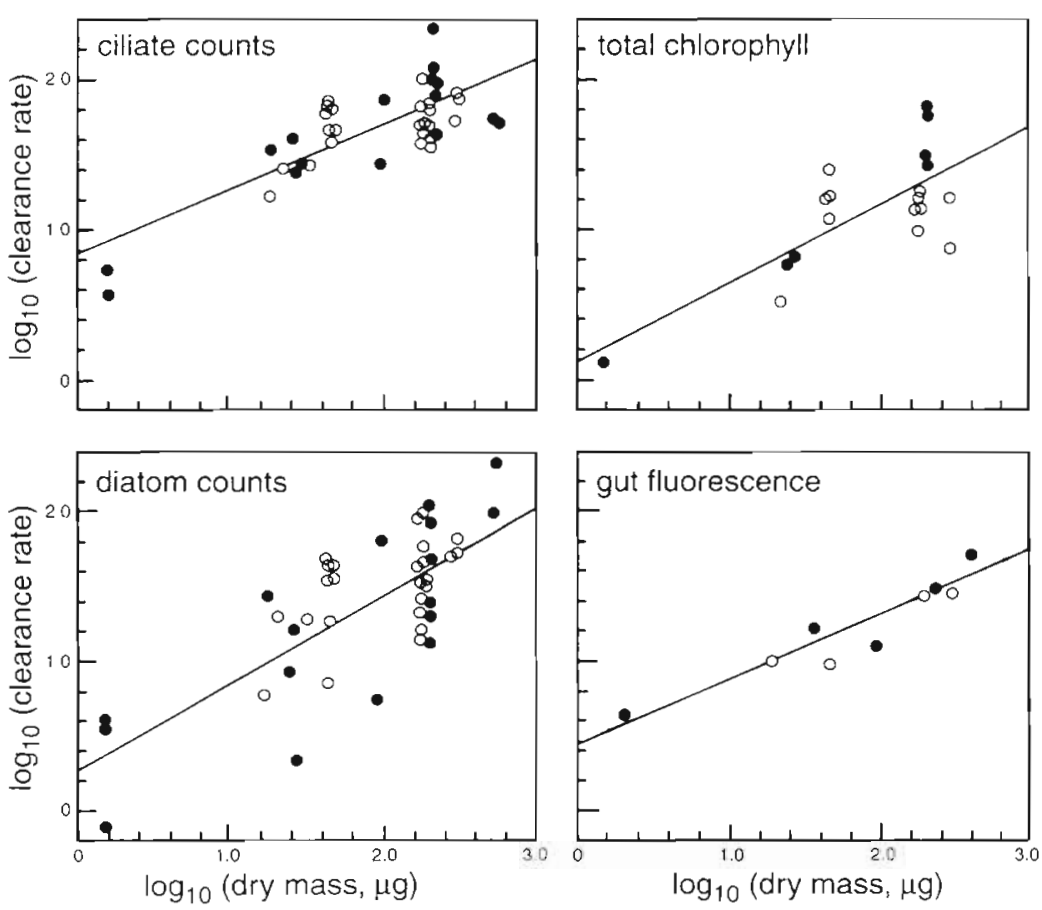

Fig. 2. Clearance rates ( $\mathrm{mI}$ ind.$^{-1} \mathrm{~d}^{-1}$ ) of ciliates, diatoms (mean of the taxa counted), total chlorophyll from the incubations and chlorophyll calculated from gut fluorescence. In the 3 incubation plots, each point represents 1 grazer bottle, whereas each point in the gut fluorescence plot is the diel mean for a species/stage. Regression lines correspond to the equations in Table 4

(O) Stages CIII, CIV, CV and CVIo of Calanus simillimus; ( ) other species calculations suggest that Calanus simillimus and Oithona spp. dominated total copepod grazing (Table 5). C. simillimus and Oithona spp. contrasted greatly in size, dominating biomass and abundance respectively, but their estimated grazing and predation impacts were about equal.

Although feeding was monitored for an array of species and stages, constituting $88 \%$ of copepod biomass, these accounted for only 50 to $80 \%$ of estimated copepod feeding (Table 5, comparing rows 3 and 4 ). This was because the regression slopes suggest that the numerous copepodites missed by the $200 \mu \mathrm{m}$ net had high mass specific feeding rates. It should be stressed that their feeding was not measured directly but extrapolated from the regression lines. It is difficult to measure feeding rates of tiny cyclopoid copepodites aboard ship, so the allometric approach remains as a best estimate, pending direct measurement. Regardless of these uncertainties, the copepods had little impact on the total phytoplankton: $<3 \%$ of the top $50 \mathrm{~m}$ water column cleared daily.

Table 4 . Regression analysis of relationships between $\log _{10}$ body mass $\left(\mu g_{1} x\right.$-value) and $\log _{10}$ clearance rate $\left(\mathrm{ml}\right.$ ind. ${ }^{-1} \mathrm{~d}^{-1}, y^{-}$ value). Regressions for the 4 different food sources/measurement methods are given, and the data are plotted in Fig. 2

\begin{tabular}{|lcccccc|}
\hline Food source & Slope & SE of slope & Intercept & F-ratio & No, of data points & p \\
\hline Ciliates (cell counts) & 0.43 & 0.056 & 0.85 & 53 & 40 & $<0.001$ \\
Diatoms (cell counts) & 0.59 & 0.081 & 0.29 & 54 & 42 & $<0.001$ \\
Total chl a (incubation method) & 0.51 & 0.12 & 0.16 & 19 & 19 & $<0.001$ \\
Total chl a (gut fluorescence) & 0.42 & 0.062 & 0.44 & 45 & $<0.001$ \\
\hline
\end{tabular}

Table 5. Estimated clearance of the copepod community in relation to abundance and biomass within the top $50 \mathrm{~m}$. Clearance values are percentages, determined for the different food sources and measurement methods. Note that not all copepodite stages of Oithona spp. Calanus simillimus and the whole copepod community were measured, so clearance rates of unmeasured stages were calculated using equations in Table 4. ${ }^{\mathrm{a}} \mathrm{Abundance}$ estimate of Oithona spp. calculated from numbers in the control bottles of the experiments

\begin{tabular}{|c|c|c|c|c|c|c|}
\hline \multirow[t]{2}{*}{ Species } & \multirow{2}{*}{$\begin{array}{c}\text { No. } \mathrm{m}^{-3} \\
\text { in top } 50 \mathrm{~m}\end{array}$} & \multirow{2}{*}{$\begin{array}{c}\text { Biomass } \\
\left(\mathrm{mg} \mathrm{m}^{-3}\right) \\
\text { in top } 50 \mathrm{~m}\end{array}$} & \multicolumn{4}{|c|}{ Percentage of 0 to $50 \mathrm{~m}$ water column cleared dally } \\
\hline & & & $\begin{array}{l}\text { Ciliates } \\
\text { (ceill counts) }\end{array}$ & $\begin{array}{c}\text { Diatoms } \\
\text { (cell counts) }\end{array}$ & $\begin{array}{c}\text { Total chl a } \\
\text { (incubation } \\
\text { method) }\end{array}$ & $\begin{array}{c}\text { Gut } \\
\text { fluorescence } \\
\text { method }\end{array}$ \\
\hline Oithona spp. (all stages) & $4520\left(3259^{a}\right)$ & 2.7 & 2.7 & 0.70 & 0.53 & 1.1 \\
\hline Calanus simillimus (all stages) & 463 & 60 & 2.4 & 1.7 & 0.62 & 0.92 \\
\hline Species/stages used for experiments & 845 & 64 & 2.8 & 1.8 & 0.71 & 1.8 \\
\hline Whole copepod community & 6367 & 73 & 5.7 & 2.6 & 1.3 & 2.2 \\
\hline
\end{tabular}


The relative impact on the various food sources reflects the overall differences in clearance rates on ciliates, diatoms $>10 \mu \mathrm{m}$ and total chl a. The greater community clearance of ciliates relative to phytoplankton reflects the higher clearance rates in Fig. 1. The clearance of total chl a calculated for the incubations is about three-quarters of that for gut fluorescence. Because both methods were measuring total chl a intake, this discrepancy must arise from methodological differences. For example, the gut fluorescence values were multiplied by 1.5 to allow for an unmeasured degree of pigment destruction. If this loss was small, however, the estimates would be in better agreement.

\section{DISCUSSION}

The 3 objectives of this study were to estimate whether the copepods could have been supported on a diet of phytoplankton only, to determine whether they were actively preying on protozoans and to estimate community grazing impact on phytoplankton and ciliate stocks.

\section{Copepod responses to food shortage}

The copepods at this site were mainly in the surface mixed layer and were feeding actively. Chl a concentrations, however, were only about $0.7 \mathrm{mg} \mathrm{m}^{-3}$ and the phytoplankton were mainly at or below the size limit for ingestion (Nival \& Nival 1976, Berggreen et al. 1988). Two independent methods suggested low daily carbon rations based on phytoplankton consumption. When gut fluorescence was used in late January in more productive oceanic waters nearer to South Georgia ( 2 to $3 \mathrm{mg} \mathrm{chl} \mathrm{a} \mathrm{m}^{-3}$ ), it showed daily rations for CV Calanus simillimus 6 times higher than were seen here (Atkinson et al. 1992). Thus, the copepods were probably facing a shortage of suitably sized phytoplankton in this oceanic, midsummer environment. An alternative explanation for low chl a ingestion rates observed in summer/autumn has been the slowing of meta-bolism in preparation for diapause (e.g. Conover \& Cota 1985, Simard et al. 1985). This is unlikely at this site because the copepods were feeding in the surface layer, with clearance rates comparable to those measured in other Southern Ocean studies (Schnack 1985, Schnack-Schiel et al. 1991, Atkinson 1994, 1995) and in the northern hemisphere at similar temperatures (Gifford 1993a, Ohman \& Runge 1994). $C$. simillimus appears to live and reproduce in the surface layers of the Polar Frontal Zone until about April (Atkinson 1991).
These daily rations of phytoplankton carbon are below the estimated respiratory requirements of active copepods. Using the equation of Dagg et al. (1982), CV Calanus simillimus, for example, would respire an estimated $6 \%$ of its body carbon per day, so carbon intake would need to significantly exceed this level to cover excretory and assimilation losses and allow for growth. Its measured algal carbon rations were only 0.85 to $2.1 \%$. Both gut fluorescence and the incubation method have been criticised for underestimating ingestion rates, but it is hard to envisage 2 methods simultaneously underestimating ingestion to such a similar and serious degree. This shortfall parallels that for Neocalanus plumchrus and $N$. cristatus in the northeast Pacific in spring, where rations based on chl a consumption were well below metabolic costs (Dagg 1993, Gifford 1993a). These northern copepods were in a low chl a environment characterised by small phytoplankton cells; factors common to this study. Gifford (1993a) found that the 2 subarctic species cleared both protozoans and diatoms $>20 \mu \mathrm{m}$ faster than they did total chl a. My Fig. 2 shows the same result with the small size of the cells dominating total chl a being a likely reason. For non bloom environments, it is being stressed increasingly that total chl a can be a poor index of food availability; other important factors are the size structure of the seston and the contribution of protozoans (Kleppel et al. 1988, White \& Roman 1992, Ohman \& Runge 1994).

The suggestion that an alternative food source was being exploited comes from the high clearance rate of protozoans relative to similarly sized phytoplankton (Fig. 1). This repeated disparity would be hard to explain in terms of experimental artefacts. For example, grazer excretion could induce growth of small autotrophs, leading to underestimates of their removal rates (Roman \& Rublee 1980 ). However, the nonlimiting macronutrients at this site and the fact that ambient concentrations of small copepods would also 'spike' the control samples suggest that the differing clearance rates were real.

Several recent studies have quantified the importance of protozoans in copepod diets (e.g. Kleppel et al. 1988, Gifford \& Dagg 1991, Fessenden \& Cowles 1994) and to copepod survival and reproduction (White \& Roman 1992, Ohman \& Runge 1994). In some of these studies, ciliates were cleared faster than phytoplankton. This might either be because they were larger than the phytoplankton present or because copepods were actively selecting protozoans by means of behavioural responses to food encounter, detection, capture, handling or ingestion (Price 1988, De Mott \& Watson 1991). Many comparisons of protozoan and diatom clearance have been complicated by the 2 foods being of different size, making it hard to decide whether the feeding pat- 
terns were size selective or predatory or both (Tiselius 1989, Wiadnyana \& Rassoulzadegan 1989, Gifford \& Dagg 1991). This study aimed to circumvent the size factor by comparing protozoans and diatoms of similar dimensions. A plausible explanation for these results is therefore of active predation on ciliates.

This study merits comparison with 2 similar studies of clearance rates of Southern Ocean copepods, because the same incubation and analysis methods were used in all these studies. In the Bellingshausen Sea in spring, Oithona spp., Metridia gerlachei and Calanus propinquus cleared ciliates, nanoflagellates and dinoflagellates more rapidly than similarly sized diatoms, whereas Calanoides acutus and Rhincalanus gigas did not (Atkinson 1995). Similar results were found near South Georgia, with small copepods (mainly Oithona spp.) showing evidence of higher clearance rates of these motile taxa relative to diatoms, but this was not evident for C. acutus and R. gigas (Atkinson 1994). The range of patterns seen (both within and among studies) lends support to the suggestion that they occur due to differing degrees of predatory behaviour among species and environments, rather than to artefacts of incubation. Copepods have been shown to have complex sensory structures and flexible feeding mechanisms, responsive to the food environment (see Price 1988). That they might detect, capture or ingest a protozoan in a different way from a similarly sized diatom would not be surprising, because the 2 foods are likely to contrast in motility, taste anc ease of handling. Also apparent in the 3 above-mentioned studies was that a diversity of taxa (ciliates, nanoflagellates, dinoflagellates) were cleared more rapidly than diatoms. This suggests that a common feature, such as motility, was involved in their removal by copepods.

Protozoans are much more nutritious than similarly sized diatoms (see Stoecker \& Capuzzo 1990) so their selection (by whatever mechanism) would have boosted food intake in this low chl a environment. An obvious question, which this study cannot address, is whether ingestion rates of protozoans plus phytoplankton could have supported the copepods. If the dinoflagellate and ciliate taxa which were counted were classed as heterotrophs, their dietary contribution would only roughly double the carbon rations of the copepods; still insufficient to meet their estimated metabolic needs. However, only a fraction of the protozoans were enumerated; motile taxa $<15 \mu \mathrm{m}$ were numerous and not counted, and it is also possible that the experimental procedures destroyed some of the athecate taxa. There were no total particulate organic carbon data available at this site, and other possible food sources not enumerated were eggs, metazoans and detritus. Alternatively, we may have indeed sampled at a time when there was not enough food for the copepods. The incubation water almost certainly would not reflect the maximum prey concentration available, but the chl a measurements at the site were not atypical for the Polar Frontal Zone at the time of our survey (J. Priddle pers. comm.). As stressed by other authors (e.g. Tiselius 1989, Gifford 1993), small-scale patchiness of the food, in conjunction with foraging behaviour, determine the prey concentrations available to a grazer. Calanus simillimus was in good physiological condition at the site, with high lipid contents (P. Ward \& G. C. Cripps unpubl.). The more likely scenario, therefore, is that their meagre phytoplankton carbon rations were being supplemented by exploitation of high concentrations of protozoans and possibly other non phytoplankton food.

\section{Copepod predation and grazing impact}

The slopes of the regressions in Table 4 reflect the relative grazing rates of large and small individuals. Moloney \& Field (1989) described typical slope values of around 0.75 . This value is higher than that seen in this study, where the scaling coefficients were in the range of 0.4 to 0.6 . These regressions were derived by 3 feeding rate methods, on several food taxa and with grazers ranging over 300 -fold in body mass. Peters \& Downing (1984) discussed wide variablity in the allometric 'constant', so possibly, like feeding activity, the scaling coefficient varies between communities. It should also be pointed out that the allometry was based on specific dietary components (total phytoplankton, diatom taxa, ciliates) and not on total carbon intake.

The value of assessing small copepods at this site is illustrated by their contribution to grazing (Table 5). Oithona spp. and Calanus simillimus constituted $4 \%$ and $82 \%$ of copepod biomass, respectively, but contributed about equally to the total grazing estimate. Together, these 2 taxa dominated copepod feeding activity. These results therefore support the suggestion (e.g. Paffenhöfer 1971, Morales et al. 1991) that small copepods can be major grazers. Paffenhöfer (1993) suggested that feeding rates of Oithona spp. were rather lower than those of similarly sized calanoids. Although their mass specific feeding rates were high in this study, Paffenhöfer's suggestion was not directly tested. The large contribution of Oithona spp. to total estimated grazing reflected their extremely high abundance at this site, underlining the importance of this ubiquitous genus.

The copepod community (excluding nauplii) removed less than $2.5 \%$ of total chl a $\mathrm{d}^{-1}$. As a percentage of the primary production of cells $>2 \mu \mathrm{m}$, this amounted to $<4 \%$ consumed $\mathrm{d}^{-1}$. (The estimate of pri- 
mary production is based on unpublished oxygen budget data by S. P. Blight.) A low copepod grazing impact has been the majority conclusion of the few oceanic studies reported (e.g. Tsuda et al. 1989, Morales et al. 1991, 1993, Dagg 1993). Because ciliates $(>15 \mu \mathrm{m})$ were cleared faster than most phytoplankton cells, a larger percentage $(5.7 \%)$ of their stocks were removed per day. I am unaware of any ciliate production estimates from the Polar Frontal Zone, but in the NE Pacific, at similar temperatures and food levels, Landry et al. (1993) measured ciliate net growth as $0.1 \mathrm{~d}^{-1}$ (rather slower than commonly measured values in warmer water with more food; see Leakey et al. 1994b). If this value were matched against the ciliate predation estimate, nearly $60 \%$ of ciliate production would have been removed. Removal by the euphausiids in the mixed layer would increase this mesozooplankton impact, although their biomass was only about one-quarter that of the copepods. At this site, the copepods therefore seem more likely to be candidates for limiting protozoan populations than for directly controlling the stocks of small phytoplankton cells.

Acknowledgements. I thank J. Cooper and Antony Atkinson for help with the cell counts, and J. Sinclair for assistance with fluorescence analysis. My thanks also goes to the officers, crew and scientists aboard the RRS 'James Clark Ross' for assistance at sea and to S. P. Blight, Dr J. Priddle and M. J. Whitehouse for providing microplankton and nutrient data prior to publication. I am also grateful to Dr E. J. Murphy, P. Ward, Dr J. Priddle, Prof. A. Clarke, R. S. Shreeve and 3 reviewers for useful comments on the manuscript.

\section{LITERATURE CITED}

Atkinson A (1991) Life cycles of Calanoides acutus, Calanus simillimus and Rhincalanus gigas (Copepoda: Calanoida) within the Scotia Sea. Mar Biol 109:79-91

Atkinson A (1994) Diets and feeding selectivity among the epipelagic copepod community near South Georgia in summer. Polar Biol 14:551-560

Atkinson A (1995) Carnivory and feeding selectivity in five copepod species at the onset of a spring bloom in the Bellingshausen Sea, Antarctica. ICES J mar Sci 52: 385-396

Atkinson A, Ward P, Williams RS, Poulet SA (1992) Feeding rates and diel vertical migration of copepods near South Georgia: comparison of shelf and oceanic sites. Mar Biol $114: 49-56$

Berggreen U, Hansen B, Kiørboe T (1988) Food size spectra, ingestion and growth of the tonsa during development: implications for the determination of copepod production. Mar Biol 99:341-352

Burkill PH, Edwards ES, Sleigh MA (1995) Microzooplankton and their role in controlling phytoplankton growth in the marginal ice zone of the Bellingshausen Sea. Deep Sea Res 42:1277-1290

Conover RJ, Cota GF (1985) Balance experiments with Arctic zooplankton. In: Gray JS, Christiansen ME (eds) Marine biology of polar regions and effects of stress on marine organisms. John Wiley \& Sons, London, p 217-236

Dagg MJ (1993) Grazing by the copepod community does not control phytoplankton production in the subarctic Pacific Ocean. Prog Oceanogr 32:163-183

Dagg MJ, Vidal J, Whitledge TE, Iverson RL, Goenng JJ (1982) The feeding, respiration and excretion of zooplankton in the Bering Sea during a spring bloom. Deep Sea Res 9:46-63

Dam HG, Peterson WT (1988) The effect of temperature on the gut clearance rate constant of planktonic copepods. J exp mar Biol Ecol 123:1-14

De Mott WR, Watson MD (1991) Remote detection of algae by copepods: responses of algal size, odors and motility. J Plankton Res 13:1203-1222

Eppley RW, Reid FMH, Strickland JDH (1970) Estimates of phytoplankton crop size, growth rate, and primary production. Bull Scripps Instn Oceanogr 17:33-42

Fessenden L, Cowles TJ (1994) Copepod predation on phagotrophic ciliates in Oregon coastal waters. Mar Ecol Prog Ser 107:103-111

Foxton P (1956) Distribution of the standing crop of zooplankton in the Southern Ocean. 'Discovery' Rep 28:191-236

Frost BW (1972) Effects of size and concentration of food particles on the feeding behaviour of the marine planktonic copepod Calanus pacificus. Limnol Oceanogr 17:805-815

Frost BW, Landry MR, Hassett RP (1983) Feeding behaviour of large calanoid copepods Neocalanus cristatus and $N$. plumchrus from the subarctic Pacific Ocean. Deep Sea Res 30:1-13

Garrison DL (1991) An overview of the abundance and role of protozooplankton in Antarctic waters. J mar Syst 2:317-331

Gifford DJ (1993a) Protozoa in the diets of Neocalanus spp. in the oceanic subarctic Pacific Ocean. Prog Oceanogr 32: $223-237$

Gifford DJ (1993b) Consumption of protozoa by copepods feeding on natural microplankton assemblages. In: Kemp PF, Sherr BF, Sherr EB, Cole JJ (eds) Handbook of methods in aquatic microbial ecology. Lewis Publishers, London, p 723-729

Gifford DJ, Dagg MJ (1991) The microzooplankton-mesozooplankton link: consumption of planktonic protozoa by the calanoid copepods Acartia tonsa Dana and Neocalanus plumchrus Murukawa. Mar Microb Food Webs 5 161-177

Head EJH (1992) Gut pigment accumulation and destruction by arctic copepods in vitro and in situ. Mar Biol 112:583-592

Hopkins TL (1971) Zooplankton standing crop in the Pacific sector of the Southern Ocean. Antarct Res Ser 17:347-362

Kiorboe T, Tiselius PT (1987) Gut clearance and pigment desctruction in a herbivorous copepod, Acartia tonsa, and the determination of in situ grazing rates. J Plankton Res 9:525-534

Kleppel GS, Frazel DW, Pieper RE, Holliday DV (1988) Natural diets of zooplankton off Southern California. Mar Ecol Prog Ser 49:231-241

Knoechal R, Holtby LB (1986) Construction and validation of a body-length based model for the prediction of cladoceran community filtering rates. Limnol Oceanogr 31:1-16

Landry MR, Gifford DJ, Kirchmann DL, Wheeler PA, Monger $\mathrm{BC}$ (1993) Direct and indirect effects of grazing by Neocalanus plumchrus on plankton community dynamics in the subarctic Pacific. Prog Oceanogr 32:239-258

Leakey RJG, Burkill PH, Sleigh MA (1994a) A comparison of fixatives for the estimation of abundance and biovolume of marine planktonic ciliate populations. J Plankton Res 16 : $375-389$ 
Leakey RJG, Burkill PH, Sleigh MA (1994b) Ciliate growth rates from Plymouth Sound: comparison of direct and indirect estimates. J mar biol Ass UK 74:849-861

Lopez M, Huntley ME, Sykes PF (1988) Pigment destruction by Calanus pacificus: impact on the estimation of water column fluxes. J Plankton Res 10:715-734

Marin V. Huntley ME, Frost BW (1986) Measuring feeding rates of pelagic herbivores: analysis of experimental design and methods. Mar Biol 93:49-58

Moloney CL, Field JG (1989) General allometric equations for rates of nutrient uptake, ingestion, and respiration in planktonic organisms. Limnol Oceanogr 34:1290-1299

Morales CE, Bedo A, Harris RP, Tranter PRG (1991) Grazing of copepod assemblages in the north-east Atlantic: the importance of the small size fraction. J Plankton Res 13:455-472

Morales CE, Harris RP, Head RN, Tranter PRG (1993) Copepod grazing in the oceanic northeast Atlantic during a 6 week drifting station: the contribution of size classes and vertical migrants. J Plankton Res 15:185-211

Nival P, Nival S (1976) Particle retention efficiencies of an herbivorous copepod. Acartia clausi (adult and copepodite stages): effects on grazing. Limnol Oceanogr 21. $24-39$

Ohman MD, Runge JA (1994) Sustalned fecundity when phytoplankton resources are in short supply: omnivory by Calanus finmarchicus in the Gulf of St. Lawrence. Limnol Oceanogr 39:21-36

Paffenhöfer GA (1971) Grazing rates of nauplii, copepodids and adults of the manne planktonic copepod Calanus helgolandicus. Mar Biol 11:286-298

Paffenhöfer GA (1988) Feeding rates and behaviour of zooplankton. Bull mar Sci 43:430-445

Paffenhofer GA (1993) On the ecology of marine cyclopoid copepods (Crustacea, Copepoda). J Plankton Res 15:37-55

Parsons TR, Maita Y, Lalli CM (1984) A manual of chemical and biological methods of seawater analysis. Pergamon, Oxford

Penry DL, Frost BW (1991) Chlorophyll a degradation by Calanus pacificus: dependence on ingestion rate and digestive acclimation to food resources. Limnol Oceanogr 36: $147-159$

Peters $\mathrm{RH}_{1}$ Downing JA (1984) Empirical analysis of zooplankton filtering and feeding rates. Limnol Oceanogr 29 : $763-784$

Price HJ (1988) Feeding mechanisms in marine and freshwater zooplankton. Bull mar Sci 43:327-343

This article was submitted to the editor
Putt M. Stoecker DK (1989) An experimentally determined carbon volume ratio for marine 'oligotrichous' ciliates from estuarine and coastal waters. Limnol Oceanogr 34: $1097-1.103$

Roman MR, Rublee PA (1980) Containment effects in copepod grazing experiments: a plea to end the black box approach. Limnol Oceanogr 25: 982-990

Saiz E, Alcaraz M, Paffenhöfer GA (1992) Elfects of smallscale turbulence on feeding rate and gross-growth eff 1 ciency of three Acartia species. J Plankton Res 14: $1085-1097$

Schnack SB (1985) Feeding by Euphuasia superba and copepod species in response to varying concentrations of phytoplankton. In: Siegfried WR, Condy PR, Laws RM (eds) Antarctic nutrient cycles and food webs. SpringerVerlag, Berlin, p 311-323

Schnack-Schiel SB, Hagen W, Mizdalski E (1991) Seasonal comparison of Calanoides acutus and Calanus propinquus (Copepoda: Calanoida) in the southeast Weddell Sea, Antarctica. Mar Ecol Prog Ser 70:17-27

Simard Y, Lacroix G, Legendre L (1985) In situ twilight grazing rhythm during diel vertical migrations of a scattering layer of Calanus finmarchicus. Limnol Oceanogr 30 : $598-606$

Stoecker DK, Egloff DA (1987) Predation by Acartla tonsa on planktonic ciliates and rotifers. J exp mar Biol Ecol 110: $53-68$

Stoecker DK, Capuzzo JM (1990) Predation on protozod: its importance to zooplankton. J Plankton Res 12:891-908

Stoecker DK, Gifford DJ, Putt M (1994) Preservation of marine planktonic ciliates: losses and cell shrinkage during fixation. Mar Ecol Prog Ser 110:293-299

Tiselius P (1989) Contribution of aloricate ciliates to the diet of Acartia clausiand Centropages hamatus in coastal waters. Mar Ecol Prog Ser 56:49-56

Tsuda A, Furuya K, Nemoto T (1989) Feeding of micro- and macroplankton at the subsurface chlorophyll maximum in the subtropical North Pacific. J exp mar Biol Ecol 132: 41-52

White JR, Roman MR (1992) Egg production by the calanold copepod Acartia tonsa in the mesohaline Chesapeake Bay: the importance of food resources and temperature. Mar Ecol Prog Ser 86:239-249

Wiadnyana NN, Rassoulzadegan F (1989) Selective feeding of Centropages typicus on microzooplankton. Mar Ecol Prog Ser $53: 37-45$

Manuscript first received: April 11, 1995

Revised version accepted: July 27, 1995 